University of Nebraska - Lincoln

DigitalCommons@University of Nebraska - Lincoln

$6-1962$

DEVELOPMENT OF SYSTEMIC INSECTICIDES FOR PESTS OF ANIMALS IN THE UNITED STATES1

R.C. Bushland

R.D. RADELEFF

R.O. Drummond

Follow this and additional works at: https://digitalcommons.unl.edu/usdaarsfacpub

This Article is brought to you for free and open access by the U.S. Department of Agriculture: Agricultural Research Service, Lincoln, Nebraska at DigitalCommons@University of Nebraska - Lincoln. It has been accepted for inclusion in Publications from USDA-ARS / UNL Faculty by an authorized administrator of DigitalCommons@University of Nebraska - Lincoln. 


\title{
DEVELOPMENT OF SYSTEMIC INSECTICIDES FOR PESTS OF ANIMALS IN THE UNITED STATES ${ }^{1}$
}

\author{
By R. C. Bushland, Entomology Research Division, \\ R. D. Radeleff, Animal Disease and Parasite Research Division \\ AND \\ R. O. Drummond, Entomology Research Division \\ Agricultural Research Service, U. S. Department of Agriculture, \\ Kerrville, Texas
}

The first encouraging results in the search for systemic insecticides were obtained in 1944 by Lindquist and his co-workers (53), who found that bed bugs, Cimex lectularius Linnaeus and $C$. hemipterus (Fabricius), died after feeding on rabbits treated orally with DDT or pyrethrins. In 1946, Knipling and associates (48) treated rabbits with oral and intravenous dosages of insecticides, and reported that rabbits tolerated treatments of lindane and 2-pivaly1-1,3-indandione at rates that were lethal to mosquitoes, Aedes aegypti (Linnaeus), and human body lice, Pediculus humanus humanus Linnaeus when feeding on the rabbits. These findings, made at the Orlando, Florida, laboratory of the United States Department of Agriculture in conjunction with wartime research on the development of military insecticides, justified the initiation of a project on animal systemic insecticides at the Kerrville, Texas, Livestock Insects Laboratory. Since that date, entomologists at Kerrville have worked intensively, screening candidate materials in the laboratory and conducting small-scale field tests with promising compounds. Concurrent toxicological observations have been made by cooperating veterinarians of the Animal Disease and Parasite Research Division, and analyses of residues of insecticides in meat and milk have been made by cooperating chemists of the Pesticide Chemicals Research Branch of the Entomology Research Division.

A description of steps in the development of the first practical systemic insecticide by the cooperative effort of entomologists, veterinarians, and chemists, both in the U. S. Department of Agriculture and from other organizations and industry, is presented below.

\section{Development of the First Practical Systemic Insecticide}

In 1947, the first test conducted at Kerrville with a systemically active insecticide involved the administration of 2-pivalyl-1,3-indandione to cattle naturally infested with short-nosed cattle lice, Haematopinus eurystermus (Nitzsch). The treatment was a dose which, in the test with rabbits cited above, was lethal to the parasite but safe for the host. With cattle, however,

${ }^{1}$ The survey of the literature pertaining to this review was concluded in June, 1962. 
both host and parasite were killed. The death of the cattle made it apparent that the economical development of a systemic insecticide would require investigation of the mammalian toxicity of compounds. Thus, veterinarians of the Animal Disease and Parasite Research Division needed to conduct toxicity tests with less expensive animals before chemicals, which appeared promising in small animals, could be used on livestock.

In 1950, deToledo \& Saur (89) reported that benzene hexachloride was systemically effective against the human bot fly, Dermatobia hominis (Linnaeus, Jr.), in cattle. On the basis of this information, chlorinated hydrocarbons were administered to cattle infested with common cattle grubs, Hypoderma lineatum (de Villers), at Kerrville, and it was noted that second- and third-instar larvae were controlled by subcutaneous injections of lindane, dieldrin, and aldrin [McGregor et al. (60)]. Unfortunately, all of the treatments caused high and persistent residues of these insecticides in the fat, which rendered treated cattle unsuitable for slaughter for many months. This finding made it obvious that chemists were needed on the team to conduct analytical research for compounds in which the objectionable residues would be eliminated. This work was necessary before entomologically effective and toxicologically safe compounds could be used in field trials involving more than a few government-owned animals.

The investigations begun in 1943 did not result in the development of a practical systemic insecticide until 1956, so there was little encouragement for other research workers to engage in the search for an animal systemic insecticide. Entomologists at the Corvallis, Oregon, laboratory of the Entomology Research Division of the United States Department of Agriculture were also engaged in an active search for systemic insecticides. Close cooperation between Kerrville and Corvallis was established, with a constant exchange of data, in order to take full advantage of laboratory facilities and field trial opportunities at both stations, thus accelerating the research.

Investigators in the Dow Chemical Company found that oral treatments of ronnel [O,O-dimethyl O-(2,4,5-trichlorophenyl) phosphorothioate] and another organophosphorus insecticide made the blood of laboratory animals toxic to mosquitoes. Roth \& Eddy (81) found that oral administration of ronnel killed second- and third-instar cattle grubs, but that the other compound was ineffective. During the previous year, McGregor, Radeleff \& Bushland (59) had reported that a number of organophosphorus insecticides killed second- and third-instar cattle grubs systemically but did not control first-instar larvae. At Kerrville, both of the Dow compounds were given to guinea pigs infested with screw-worms, Cochliomyia hominivorax (Coquerel); ronnel failed to kill the screw-worms at a screening dose of $50 \mathrm{mg} / \mathrm{kg}$ of body weight administered orally to the guinea pigs, whereas the other compound was effective at a much lower dosage.

Because, in the Kerrville area, cattle grubs appear in the backs of cattle as early as August, tests at Kerrville could be started six months earlier than at Corvallis to determine whether either compound would be effective 
against first-instar larvae. After consideration of the Corvallis results, each compound was administered orally to groups of five Hereford calves in June 1955. Records, completed by November, showed that ronnel was systemically active against first-instar larvae, and was the first insecticide to be effective in that manner.

As a result of this finding, more cattle were treated at the Corvallis laboratory in the fall of that year, and, at Kerrville, additional tests were conducted with grub-infested cattle imported from South Dakota. The preliminary results were confirmed at both laboratories [McGregor \& Bushland (57); Roth \& Eddy (81)]. The results were sufficiently conclusive to justify metabolism and residue studies with $\mathrm{P}^{32}$-labeled ronnel furnished to both laboratories by Dow Chemical Company. These unpublished studies by W. E. Robbins at Corvallis and J. N. Kaplanis at Kerrville showed that there was not a serious residue hazard, provided a suitable interval was observed between treatment and slaughter. Concurrent toxicological studies made by Radeleff \& Woodard (75) and a field trial by Jones, Brundrett \& Radeleff (46) indicated that the chemical could be safely administered to privately owned cattle in large-scale field tests. The close cooperation between the two laboratories and the Dow Chemical Company, and the team work of entomologists, veterinarians, and chemists, accelerated the development of this systemic insecticide.

The work on ronnel was coordinated by Lindquist (51), who first announced its effectiveness in 1956. He invited Extension and State Experiment Station workers and Canadian entomologists and veterinarians, to Kerrville for a special conference on the insecticide. At that meeting, the data accumulated by workers of the United States Department of Agriculture and the Dow Chemical Company were presented.

The Department of Agriculture cannot recommend a treatment to livestock producers until certain practical field evaluations are made. These evaluations are needed to establish the effectiveness and safety of an insecticide at a variety of geographical locations under a multitude of variable farm and ranch conditions. The rapid practical field development of ronnel resulted from the enthusiastic critical evaluation by state and Canadian workers who promptly explored its effectiveness and limitations.

The foregoing account of the investigations which led to the first recommendation of a systemic insecticide for livestock illustrates the problems encountered and the team work required. Further details about experimental design and test procedures which have resulted in the development of a variety of chemicals and methods of treatment, not only for cattle grubs but also for several other pests, can now be reviewed.

\section{Screening Procedures}

The laboratory procedures used for screening systemic insecticides have been thoroughly described by Graham (34); thus, they need only be outlined here. 
Laboratory tests against cattle grubs-The test procedure employed at Kerrville from 1947 to 1951 was that devised by Barrett \& Wells (4). This technique was tried because first-instar larvae of Hypoderma lineatum could be dissected from gullets of slaughtered cattle and kept alive in bovine serum in an incubator for $48 \mathrm{hr}$. The larvae could also be transplanted into white mice, where they survived and grew for several weeks. During many months of the year, an abundance of larvae could be cheaply and easily obtained from slaughter houses.

Preliminary tests were made by adding solutions of candidate insecticides in Tween-20 (polyoxyethylene sorbitan monooleate) to $10-\mathrm{ml}$ quantities of bovine serum to obtain a concentration of $400 \mathrm{ppm}$. Five larvae were placed in the beaker containing the serum, which was then held for two days at $30^{\circ} \mathrm{C}$. If the larvae were killed, progressively lower concentrations were tested until the insects survived. Of 1628 compounds tested by this method, 178 were toxic at $400 \mathrm{ppm}, 96$ at $200 \mathrm{ppm}, 30$ at $100 \mathrm{ppm}, 10$ at 50 $\mathrm{ppm}$, and 4 at $25 \mathrm{ppm}$. Compounds that were toxic to larvae in this in vitro test were injected into mice that had been infested a week earlier with five larvae. A week after treatment, the mice were sacrificed. Examination of larvae showed that none of the compounds killed larvae at a dose tolerated by mice. However, it was found that chemicals injected into mice could be transported within the body to reach Hypoderma larvae in loose connective tissue, since larvae dissected from mice treated with Eosine $\mathrm{Y}$ (bromoeosine) and Atabrine dihydrochloride ${ }^{\circledR}$ (quinacrine hydrochloride) were characteristically stained.

This screening technique was abandoned after four years because certain chemicals such as lindane failed against first-instar larvae in the laboratory screening test, even though they would kill second- and third-instar grubs in cattle. The chemicals presently known to be effective against firstinstar larvae in cattle were not available during the years that the "beakerand-mouse" screening test was in use. Lack of success at Kerrville may have been attributable merely to the fact that the samples of 1628 candidate compounds tested did not contain systemically active insecticides that provided an adequate margin between a larvicidal concentration and a dose toxic to the mouse. R. O. Drummond (unpublished data) found ronnel to be ineffective when given orally to mice artificially infested with first-instar Hypoderma lineatum larvae. Certainly, a variety of cattle grub systemics should be tested in a re-evaluation of the in vitro procedure and the mouse test.

Tests with infested guinea pigs.-When the procedure devised by Barrett \& Wells (4) was abandoned (at Kerrville), a technique was developed [McGregor \& Bushland (56)] for in vivo screening with guinea pigs as hosts and screw-worm larvae as the parasites. In that technique, a guinea pig was artificially wounded on the hip by removing a small disc of skin and subcutaneous tissue to expose muscle, and 50 newly hatched larvae were 
implanted in the wound. After $24 \mathrm{hr}$, when the larvae were established and growing, a solution or suspension of test material in Tween-20 was administered subcutaneously at a dosage of $25 \mathrm{mg} / \mathrm{kg}$ body weight. Later, the screening dose was doubled and test chemicals were administered orally as well as subcutaneously to the guinea pig.

The early work was retarded by elaborate observations that were made to determine whether chemicals that failed to kill the larvae would interfere with their growth in the host, pupation, and emergence. Those flies which emerged were held routinely for mating, oviposition, and fertility records. However, it was soon noted that several chemicals could be tolerated by the hosts at dosages which killed larvae within $48 \mathrm{hr}$. For this reason, the test was simplified to eliminate those chemicals that permitted larvae to grow normally for $48 \mathrm{hr}$.

If an administered dose killed a guinea pig quickly, the chemical was retested at a lower dosage. However, if a guinea pig died within a few hours after treatment, the dead animal was placed in an incubator to maintain its body temperature so that the larvae could continue growing. If the larvae survived after $24 \mathrm{hr}$, the chemical was discarded. Chemicals that killed larvae and were tolerated by the host were tested at progressively lower dosages until an ineffective dose was reached. This procedure detected the systemic effects of lindane, dieldrin, and aldrin, and became established at Kerrville as the screening procedure of choice.

The three chlorinated hydrocarbons just mentioned were found to be systemically active against second- and third-instar cattle grubs, but the treatments were impractical because of excessive residues of the chemicals. Therefore, attention was turned to the phosphorus insecticides. McGregor \& Bushland (56) had early success with several phosphorus compounds given to guinea pigs, and when these compounds were tried in cattle they killed second- and third-instar larvae but not first-instar larvae.

The screening procedure was amended by increasing the highest dosage from 50 to $100 \mathrm{mg} / \mathrm{kg}$, since tests with ronnel (discussed in the introduction) had shown that the initial screening dosage was too low. Screening observations were not limited to screw-worms; starved stable flies, Stomoxys calcitrans (Linnaeus), also were allowed to feed on the clipped bellies of guinea pigs $4 \mathrm{hr}$ after treatment. The flies that fed were held for $24 \mathrm{hr}$ to see if they were killed by the blood they had ingested.

In 1956, further improvements in the screening program were made [Drummond (22)]. Routinely, stable flies were allowed to feed on the guinea pigs at $24 \mathrm{hr}$ as well as $4 \mathrm{hr}$ after treatment, to increase the chances of detecting a systemic for stable flies. Also, lone star ticks, Ámblyomma americanum (Linnaeus), were added to the screening test by confining 10 starved nymphs in a small plastic cage taped and cemented to the body of the guinea pig $48 \mathrm{hr}$ before treatment. In such a test, the ticks were engorging at time of treatment. Acaricidal effects were evaluated by noting whether the ticks completed engorgement or survived to molt to adults. 
Drummond (24) has presented a brief history of the screening technique and summarized the results with 438 compounds screened by the guinea pig test during the years 1953 through 1959. Tabulations show that the procedure was remarkably effective in detecting systemic activity. Of the 438 compounds tested, 126 were systemically active. Of those active compounds, 36 were also toxic to the guinea pigs at the minimum effective dose, but 90 killed parasites at dosages tolerated by the host. Of these 90 compounds, 64 killed screw-worms, which were generally most susceptible. Eighteen compounds killed all three parasites-ticks, stable flies, and screw-worms. As an indication of specific action, it was noted that 36 compounds killed only screw-worms; 11 , only stable flies; and 4 , only ticks. With such evidence of parasite specificity, one can easily ascertain that it is most desirable to screen against ticks and stable flies as well as screw-worms.

Tests with mice.-Hewitt and his co-workers $(42,43)$ of the American Cyanamid Company developed a screening procedure by which candidate insecticides are administered to mice, and Aedes aegypti are allowed to feed on the mice at intervals after treatment. In their testing, these workers placed special emphasis on the detection of compounds that provided a margin of safety between the insecticidal dosage and the toxic dosage. They established a dosage that killed 50 per cent of the test insects $\left(E D_{50}\right)$ and another that killed 50 per cent of the test mice $\left(\mathrm{LD}_{50}\right)$. The $\mathrm{LD}_{50}$ for mice divided by the $\mathrm{ED}_{50}$ for mosquitoes gives a figure which they call the "chemotherapeutic index." With regard to this index, it is apparent that there is as much variation between species of mammals in susceptibility to insecticide poisoning as there is between species of insects, and the chemotherapeutic index will vary among species of both insects and mammals.

Stones (88), in a review of work on systemic insecticides in England, reported on a laboratory screening test conducted at the Cooper Technical Bureau, Berkhamsted, Herts, in which treated mice were exposed to attack by starved stable flies.

At the Corvallis laboratory, candidate systemics were administered to mice in a screening test described by Lindquist et al. (54). Workers there used a novel approach to obtain laboratory data on economically important insects that were abundant outdoors. Treated white mice were closely confined in hardware-cloth cages and exposed outdoors in open quart fruit jars to attack by deer flies, Chrysops discalis Williston, and mosquitoes, Aedes dorsalis (Meigen). Those insects which took a blood meal were captured and held for mortality observation. The tests proved the systemic effectiveness of dieldrin, aldrin, and lindane, and showed that valuable data could be obtained at a minimum of expense by taking advantage of natural conditions.

Tests with rabbits.-Several workers have used domestic rabbits as host animals for laboratory tests. The first published reference to the systemic activity of lindane was made by de Meillon (62), who showed that bed bugs, mosquitoes [A. aegypti], and ticks [Ornithodoros moubata (Murray)] were 
killed by treatments tolerated by rabbits. Garnham (32) also found that mosquitoes were killed when they fed on rabbits dosed with lindane.

At Alabama Polytechnic Institute, Auburn, Alabama, Adkins and his co-workers $(1,2)$ administered insecticides to rabbits on which nymphal Gulf Coast ticks, Amblyomma maculatum Koch, or lone star ticks were engorging, and subsequently allowed bed bugs to feed on the treated animals. Flynn \& Eden $(29,30)$ used these arthropods and also yellow-fever mosquitoes and stable flies to evaluate several groups of insecticides. Later, Brady, Dorough, \& Arthur (12) and Dorough \& Arthur (20), using the same methods, screened additional chemicals.

In the first experiments at Orlando, Florida, rabbits weree also used as host animals. No doubt, valid data can be obtained by using rabbits but there are two objections to their use in a large-scale routine screening program. One is that rabbits are more expensive as laboratory animals than are guinea pigs or mice. The second, even more important, is that first samples of new compounds for screening are usually available only in very small quantities; thus, to obtain the maximum data with a minimum of material, one should employ smaller laboratory animals.

\section{Development of Dermal Systemic Insecticides}

It is apparent that with the guinea pig screening test as employed at Kerrville, not all chemicals with systemic activity will be detected. For example, treatment of guinea pigs by subcutaneous injection may be inadequate for detecting systemics that would be effective when applied dermally. It is not practical to make dermal applications on these small animals, since so much of their body surface is utilized as feeding areas for stable flies and for cages containing ticks. Such areas must be protected to eliminate contact kill of test arthropods.

Co-ral ${ }^{\circledR}$ (Bayer 21/199, O,O-diethyl O-3-chloro-4-methyl-2-oxo-2H-1benzopyran-7-yl phosphorothioate) was tested at the Kerrville laboratory because Farbenfabriken Bayer scientists had found it to be effective against ticks as a contact acaricide. Smith \& Richards (86), comparing a number of phosphorus compounds with rotenone as back treatments against encysted cattle grubs found Co-ral to be highly effective. Since other work at Kerrville had shown that sprays of Co-ral left deposits on the hair with prolonged residual insecticidal effects, heavy concentrations were applied to the backs of infested animals to see whether new grubs migrating there after treatment would be killed by the residue after the grubs had cut holes in the skin.

Brundrett, McGregor \& Bushland (13) treated Texas cattle at the beginning of the 1955 grub season. Grubs continued to appear in the backs of untreated animals, but no new grubs encysted in those treated with Co-ral. This observation suggested the probability that the dermal treatment had acted systemically against first-instar larvae. In July, 1956, a special test was conducted in which cattle were sprayed with emulsions and suspensions 
of 0.75 per cent Co-ral. Grubs began to appear in the untreated animals in August. By the end of the grub season, untreated calves had harbored an average of 37.2 grubs per animal in their backs, whereas the average was only 0.2 in the backs of those treated with Co-ral; thus, the systemic effectiveness of the single dermal treatment against first-instar larvae was confirmed. Similar results were also obtained from additional tests in the fall with calves imported from South Dakota [Graham (33)].

\section{Preliminary Trials}

At Lethbridge, Alberta, Canada, a technique was developed by Weintraub (93) for rearing flies from grubs taken from infested cattle, mating these flies in the laboratory, and inducing them to oviposit on cattle to obtain uniform infestations. This technique is valuable for precise biological investigations [Weintraub et al. (94)] and has been used to assure adequate infestations of grubs in small groups of cattle [Beesley (8)].

However, it is less expensive and time-consuming to conduct tests with naturally infested cattle. At Kerrville, two groups of naturally infested cattle are used for preliminary field tests. One herd of cattle is maintained on government-owned pastures at Camp Stanley, Texas. A high infestation rate occurs in the calves and yearlings, as indicated by the grubs that mature in untreated animals and in those treated with systemically ineffective insecticides. These animals are used in tests conducted during the summer months against first-instar Hypoderma lineatım, which begin to appear in the animals' backs in August-September. Each fall, additional calves are purchased from South Dakota or Wyoming ranches; these animals usually have heavy infestations of both $H$. bovis and $H$. lineatum which appear in the animals' backs in January. These northern cattle are treated in November and December, on the basis of information obtained on the effectiveness of insecticides administered to local cattle. Thus, with the addition of the northern cattle, two separate series of preliminary trials can be conducted. The Corvallis laboratory also initiates treatments in the fall on small numbers of local cattle that are infested with both species of grubs.

In initial tests with phosphorus insecticides [McGregor \& Bushland (56) ], these compounds were administered to local cattle in which grubs had appeared in the animals' backs. Thus, data were obtained on the control of second- and third-instar larvae, and also on the systemic effect against first-instar larvae by observing the appearance of new grubs in the animals' backs. Treatment at this stage of grub development has been discontinued, because widespread field use of Co-ral and ronnel by other workers has indicated that these systemic insecticides are more effective against firstinstar larvae if applied at least one month before grubs are due to appear in the back. Therefore, it may not be a true test of the effectiveness of a material against first-instar larvae to apply it while the larvae are in the process of migration.

In these preliminary trials, two to five animals constitute a treatment 
group. If grub-infested catîle are being tested for the first time with the candidate systemic, only two or three animals are treated, because the chemicals fail more often than they succeed. Also, these cattle are treated with the systemic at a high level-one which veterinarians have determined will be slightly toxic but not lethal. If the insecticide fails at this high dosage, it is not given further consideration. If an insecticide is being retested at a higher or lower dosage, or if an effective compound is being applied by a new method, about five cattle per treatment group are used, so that differences in numbers of grubs appearing in backs of treated and untreated cattle will be more significant.

The first tests with new systemic insecticides in grub-infested cattle are dual investigations-entomological and toxicological. Treatments found to be effective in the laboratory are administered to cattle by an entomologist working jointly with a veterinarian. The veterinarian takes blood samples before and after treatment for laboratory studies, and keeps the animals under close observation after treatment to note any objective evidence of poisoning, and controls any poisonings that may develop. The animals are kept on the laboratory premises until blood cholinesterase activity has started to return to normal or the animals are believed to be normal. Then they are moved to pasture.

All treated and untreated cattle are examined at monthly intervals or more often. At these examinations, individual encysting cattle grubs are located on outline maps of the backs of the cattle. As new grubs appear, the number observed can be added to the total of grubs already found. Thus, cumulative counts of grubs in each animal can be obtained, and counts can be made without disturbing the grubs, so that they can continue their life cycle. In this way, adequate infestations can be assured for the next generation of grubs.

\section{Metabolism Studies}

In order that a chemical may function as a systemic insecticide against livestock insects, either the parent compound or a metabolite of the material must be transported within the body away from the site of administration to an area where it will kill parasites within the body of the host or ectoparasites feeding on the blood. The chemical should not be metabolized too rapidly or it will not survive within the animal long enough to kill the pest. However, it should not be so persistent that a prolonged interval will be required between treatment and slaughter to overcome the residue hazard.

The chlorinated hydrocarbon insecticides cannot be used as general livestock systemics because residues of entomologically effective treatments persist for too many months [Claborn, Radeleff \& Bushland (17)]. The phosphorus insecticides are much less persistent. In general, these compounds are completely eliminated, chiefly in the urine, within 60 days, which constitutes a reasonable interval between treatment and slaughter.

After entomological tests have shown that a new chemical is effective 
for livestock insect control, it usually requires a year or more for the chemists to develop precise analytical methods sufficiently sensitive to detect less than $1 \mathrm{ppm}$ of an insecticide or its metabolites. Fortunately, the phosphorus insecticides can be synthesized as radioactive compounds labeled with $\mathrm{P}^{32}$. Usually, $\mathrm{P}^{32}$ labeling is all that is essential for a metabolism study, but, if necessary, other parts of the molecule can be labeled with $\mathrm{C}^{\mathbf{1 4}}$. It is not difficult for chemists to synthesize a radioactive $\mathrm{P}^{32}$ insecticide with a specific activity of at least $2 \mathrm{mc}$ per gram. Five $\mathrm{mc}$ of a radioactive $\mathrm{P}^{32}$ insecticide given to a 500-pound calf is sufficient for residues to be detected in tissues, blood, or excretory products with a sensitivity of $0.01 \mathrm{ppm}$.

Plapp, Chamberlain \& Radeleff (72) have reviewed the literature and summarized the metabolism studies made with radioactive ronnel, Co-ral, dimethoate, and Ruelene ${ }^{\circledR}$ (O-4-tert-butyl-2-chlorophenyl $O$-methyl methylphosphoramidate). In their review, they cite 29 references to experiments conducted in state and United States Department of Agriculture laboratories. Another summary by Weidhaas, Schmidt \& Chamberlain (92) lists 21 references, most of which pertain to metabolic studies of systemic insecticides in mammals.

To date, all of the systemic insecticides given to lactating cows have been detected in the milk, so they cannot be used to treat lactating dairy animals without discarding several days' milk. Ronnel, Co-ral, and dimethoate have been found in the blood as parent compounds and as their oxygen analogues. With ronnel, peak concentrations occurred in the blood after 8 $\mathrm{hr}$, but neither the parent compound nor its oxygen analogue could be found after $60 \mathrm{hr}$. Residues of the insecticide were stored in fat, but they disappeared within 60 days.

Sprays of Co-ral were poorly absorbed and most of the chemical remained on the skin and hair. An animal stanchioned so that it could not lick itself absorbed only about 5 per cent of the dermally applied dose, whereas an animal free to lick absorbed about twice as much. When Co-ral was given orally, it was eliminated about equally in the feces and in the urine. A large proportion of the material in the feces was found to be the unchanged parent compound, which indicated that an oral treatment was poorly absorbed from the digestive tract. Small amounts of the parent compound and its oxygen analogue were stored in the fat, and residues disappeared within 45 days.

Dimethoate was most rapidly absorbed and eliminated. When radioactive material was given intramuscularly, 90 per cent of the applied dose was eliminated in the urine in $9 \mathrm{hr}$. When given orally, the compound was 90 per cent eliminated in $24 \mathrm{hr}$ and only trace amounts were found in the feces, which proved that the material was almost completely absorbed from the digestive tract. Dimethoate treatments caused only small amounts of residues. Maximum storage in the fat was $3 \mathrm{ppm}, 3 \mathrm{hr}$ after treatment, but only $0.1 \mathrm{ppm}$ after $8 \mathrm{hr}$. Residues were largely eliminated from all tissues within 14 days. Since dimethoate showed particular promise against sheep 
bot flies, Oestrus ovis Linnaeus [Peterson et al. (69)], its metabolism in sheep was given special study by Chamberlain, Gatterdam \& Hopkins (15). The metabolic picture for sheep was similar to that found for cattle. Only trace residues could be found four weeks after treatment.

Ruelene was discovered by workers in the Dow Chemical Company as a result of metabolism studies with Dowco-109® [O-(4-tert-butyl-2-chlorophenyl) $O$-methyl methylphosphoramidothioate]. It was found that Dowco109 was converted to the oxygen analogue which functions systemically. Therefore, the Dow Chemical Company synthesized this metabolite, called Ruelene, for use as an insecticide. Ruelene acts as a systemic when administered orally, intramuscularly, or dermally [McGregor, Ludwig \& Wade (58) ]. Plapp and his co-workers (72) reported that not more than 42 per cent of the administered compound could be recovered from the urine and feces, and 7 to 11 metabolites were involved. The majority of the compound is converted to phosphoric acid, which is incorporated in the normal phosphorus metabolism of the treated animal.

\section{Toxicological Considerations}

An ideal systemic insecticide, besides having broad entomological effectiveness, would be safe for livestock and leave no residue in their tissues or in their products that would be a food hazard. All of the presently available compounds fall short of this ideal. The extensive literature on toxicity and residue hazards has been reviewed by Radeleff \& Bushland (74) and Claborn, Radeleff \& Bushland (17).

The gap between screening with small laboratory animals and application to livestock in field trials must be bridged slowly to avoid unnecessary losses. Various research groups have developed different systems to bridge this gap. The techniques employed at the Kerrville laboratory are fundamental and have been used as guides by most of the other research groups, but have not by any means been regularly duplicated in their regular programs.

The dairy calf less than two weeks old generally represents the most susceptible of all farm animals. This factor is fortunate, because the cost of such calves is usually rather low. At the Kerrville laboratory, preliminary farm animal toxicology studies are conducted with such young calves.

Selecting the initial exploratory dosage is, to a degree, a matter of intuition. Realistically, however, it is usually based upon a dose equivalent to one-fourth of that producing symptoms or death in guinea pigs during the preliminary entomological screening. As often as not, this dose must be increased or decreased according to the reaction of the calf.

Visual observation of the treated animals is the most reliable technique for detecting any effect. With the cholinesterase-inhibiting compounds, periodic determinations of this enzyme's activity in blood have been useful in selecting additional dosages for study.

For preliminary studies of systemic insecticides in infested animals at Kerrville, dosages are selected, based on data from tests with young calves, 
that are expected to induce a degree of poisoning that can be controlled by the known therapeutic methods. By selecting these dosages, many compounds can be eliminated from further consideration, since entomological failure at a dosage toxic to the host is obviously a total failure. When a compound is entomologically effective at such dosages, the next procedure is a step-wise reduction of the dosage until the minimal effective dosage against the pest is reached.

For field investigation, the dosage selected is preferably one-half that known to produce the mildest of effect in young calves. With cholinesterase inhibitors, there should be no more than a 25 per cent reduction of the enzyme activity in the blood. Certain situations will arise from time to time in which such a margin cannot be maintained, but the calculated risk is much less than the value to be obtained from the control of the pest. Although the procedure outlined gives useful data and a general orientation concerning the compound and its characteristics, additional studies must follow to reveal all of its peculiarities.

Each mammalian species to be treated must be studied directly. So much variation exists among the species of farm animals, with additional variations with each chemical, that the transfer of data from one to the other is ill-advised. Further, undernourished and emaciated animals may respond in a vastly different way than their better nourished counterparts. This effect, together with that of lactation, was spectacularly demonstrated with sheep dipped in benzene hexachloride [Radeleff \& Bushland (73)]. Stress in any form may influence both toxicological reaction and biological effectiveness.

The conditions must always be considered under which the farmer and rancher will use the material, since "normal" practice for them may include surgical procedures, administration of anthelmintics and immunizations, in addition to the administration of systemic compounds, all in one day.

Recognition of poisoning.- Under controlled research conditions, the symptoms to be expected in poisoned animals can be clearly demonstrated. Chlorinated hydrocarbon insecticides affect the central nervous system, producing symptoms that include hypersensitivity, muscular twitches and spasms, abnormal posturing and behavior and, often, convulsive seizures. In other instances, the animals become depressed and fail to eat or drink. The organic phosphorus compounds also affect the nervous system, producing salivation, difficult breathing, and stiff walking movements. In some cases, there are gastrointestinal effects, including diarrhea and colic. Recognition of these two classes of poisoning would be simple, except that many compounds elicit multiple responses.

In studies with ronnel, an initial phase of chlorinated-phenol-like poisoning is recognized, followed later by symptoms normally associated with the organic phosphorus compounds. Co-ral usually results in the organic phosphorus syndrome, followed later by symptoms similar to those observed with chlorinated hydrocarbons. Such two-part poisonings are associated with the 
higher dosages. Lower dosages usually produce only the first part in each case.

The reaction of an observer to a given case will vary according to the stage of the poisoning when the animal is first observed. In the absence of information concerning treatment or in the instance of multiple exposures, a diagnosis may be difficult. Further complications occur, in that various symptoms of poisoning are indistinguishable from those found in diseases such as rabies and other encephalitides, and poisonings by certain plants and other chemicals.

Treatment of poisoning.-Because of the deliberate selection of maximal doses for initial screening against cattle grubs and other parasites, methods were needed for controlling the resultant poisoning.

Chlorinated hydrocarbon insecticide poisoning must be treated symptomatically, because there are no known pharmacological antidotes. For most purposes, the administration of chloral hydrate or of barbiturates has been satisfactory. In practice, this should be supplemented by removal of the poison by washing or purgation wherever possible.

Atropine sulfate is a pharmacological antidote for many organic phosphorus insecticide poisonings. It must be given until effective and requires that larger dosages be employed than are normally suggested.

Unfortunately, because of the long period of poisoning associated with ronnel or Co-ral, atropine leaves much to be desired. Its use in these cases suffices to control symptoms momentarily, but its repeated use during several days will exhaust the patient. Here, too, removal of the poison by washing or purgation is indicated and beneficial. No specific or diagnostic lesions are found associated with deaths that are caused by these insecticides, thereby increasing the difficulty of diagnosis.

A "side reaction" has been observed in cattle given systemic insecticides and involves a posterior paralysis. The paralysis may be unilateral or bilateral, involving muscles of the lumbar region and the hind limbs. Furthermore, seizures may last for only a few seconds or they may be prolonged. This reaction appears to involve only those cattle infested with Hypoderma bovis larvae, and then only at a certain stage in their larval development. The involvement is not due to a specific chemical action, but the chemical is usually held to be responsible.

Edematous infiltrations of the oesophagus have been noted in cattle treated for control of Hypoderma lineatum. Apparently, the poisoned grubs suddenly become unacceptable to the bovine tissues and intense reactions take place. The infiltrations seem to begin in the submucosal tissues, with leakage of the edema fluid into the muscular coats. Animals so afflicted have difficulty in swallowing food, even saliva. When the normal flow of saliva cannot be swallowed, it must leave by the mouth, thereby giving the animal the appearance of excessive salivation as observed in organophosphorus insecticide poisoning. This reaction is not specific intoxication with the insecticide but is the result of destruction of the larvae. 
Organoleptic changes.-Seldom mentioned in discussions of this type, perhaps because the considerations are fundamental, is the requirement that systemic insecticides shall not induce organoleptic changes in the animal products. These are aesthetic considerations, but they must be met or consumer resistance will negate the usefulness of the material. Undesirable colors, flavors, odors, and textures must not result. The quality of the systemic circulation of these compounds makes them particularly likely to produce such characteristics.

All of the organophosphates developed at date (July 1962) as animal systemics have been found in the milk of lactating cows; therefore, their application to dairy animals is not recommended. Before Co-ral and ronnel were recommended as treatments for beef animals, appropriate tests were made with the cooperation of the Human Nutrition Research Division, Agricultural Research Service, of the United States Department of Agriculture. Cattle were treated at Kerrville according to anticipated recommendations and sacrificed within the time proposed to intervene between treatment and slaughter. Various cuts of meat were frozen and shipped to Beltsville, Maryland, where they were cooked by home economists and evaluated by a panel of taste experts. Any "off" flavors or odors would have required further appraisal of the treatments. Such "taste tests" are an essential step in developing any new systemic insecticide for animals.

\section{Field Evaluation of Systemic Insecticides}

Because facilities of Department of Agriculture field laboratories are too limited, it is not possible for scientists of that agency to make an evaluation of a systemic insecticide sufficient for a nationwide recommendation. In the United States Department of Agriculture, research aims are to investigate new compounds and to try new methods of administration. Treatments are tested on a scale large enough to eliminate ineffective chemicals, inadequate dosages, or unsatisfactory methods of treatment, and promising treatments are brought to the attention of workers at other laboratories for final evaluation. Results of recent screening tests and preliminary tests against cattle grubs with several effective systemics have been reported by Drummond $(23,26)$.

As mentioned earlier, state and Canadian workers were invited to Kerrville in the summer of 1956 for a review of data on ronnel. In 1957, a second conference was held at Kerrville. At this meeting, these workers reported on their extensive field trials of the insecticide in several states and Canada. The data exchanged at this meeting were sufficient for the Dow Chemical Company to satisfy all requirements for registration to market the insecticide, and for state and federal workers to recommend this first cattle grub systemic.

At the 1957 meeting in Kerrville, representatives of the Kerrville and Corvallis laboratories reviewed their exploratory tests with Co-ral so that state workers would have the information in time to test sprays of that 
chemical in the same season. In addition, preliminary data on the effectiveness of dimethoate were presented.

The mutual exchange of information between federal, state, Canadian and industrial representatives proved so valuable that workers voted to continue such annual conferences, in order to share information more rapidly than could be done through publications, and more thoroughly than would be feasible at regular meetings of scientific societies having broader programs in medical and veterinary entomology.

Beginning in 1958, the systemic insecticides conference was sponsored jointly by Section D of the Entomological Society of America, the Entomology Research Division, and the Animal Disease and Parasite Research Division, United States Department of Agriculture. In 1958, the meeting was held on the campus of Kansas State University; in 1959, at the University of Wyoming; in 1960, at Purdue University; in 1961, at Mississippi State University; and in 1962, at the University of Nebraska.

In this account, space prohibits citing all of the publications on the field use of systemic insecticides for cattle grub control. Almost every issue of the Journal of Economic Entomology since 1958 has contained papers on systemic insecticides for cattle grub control. The literature citations in these papers also refer to publications in other journals. Reviews of some of the earlier laboratory and field work have been written by Bushland (14), Lindquist (52), McDuffie (55), and Peterson \& Kingscote (68).

In addition to field trials conducted in the United States and Canada, workers in other countries have been actively testing systemic insecticides for control of cattle grubs. In Germany, Bolle (10) and Rosenberger (78) reported that three oral treatments with Dipterex ${ }^{\circledR}$ (dimethyl 2,2,2,-trichloro-1-hydroxyethylphosphonate), one month apart, were highly effective. Additional data on the effectiveness of Dipterex administered dermally as well as orally have been presented by Sassen \& Otte (83) and Rosenberger (80). Dipterex was tested in Hungary by Stoenescu et al. (87) and Nemcseri (65), in Italy by Nardí \& Lellis (64), in Great Britain by Beesley (7), and in India by Sharma et al. (85). There is a vast Russian literature on the effects of systemics and other insecticides on cattle grubs and other parasites. A summary of this literature by Grunin $(37,38)$ has been translated into English in the Entomological Review. Apparently much work is being done with "chlorophos" or Dipterex. Ronnel has been used in Ireland [Kenny \& Thornbury (47); Hatch (41); Baxter (5); Pearson \& Baxter (67)] and in Great Britain [Beesley (6); Stones (88)].

In England, Beesley (8) presented a review of experimental techniques used in his laboratory, and Stones (88) reviewed some of the developments in the field of systemic insecticides.

With another systemic insecticide, Ruelene, the preliminary experiments were conducted by workers of the Dow Chemical Company. Recent publications have shown that this compound is highly effective against first-instar larvae of the cattle grub when applied as a spray or as a "pour-on" treatment [Rogoff \& Kohler (77); Scharff \& Ludwig (84)]. 
Another compound which shows a great deal of promise as a systemic treatment for the control of cattle grubs is Famophos ${ }^{\circledR}$ (O,O-dimethyl $O$ $p$ (dimethylsulfamoyl)phenyl phosphorothioate) of the American Cyanamid Company. Data presented at the Annual Livestock Systemic Insecticides Conferences in 1961 and 1962 indicate that this insecticide is effective when administered intramuscularly, as a pour-on treatment, or in feed.

\section{Methods of Treatment with Systemic Insecticides for Cattle Grubs}

Initial tests and subsequent field tests with ronnel were conducted with the compound administered as a bolus or an oral drench. The insecticide is also administered by adding measured amounts of ronnel to the feed of cattle. This low-level method of administration has proved to be effective, and a feed-additive formulation of ronnel is marketed in the United States under the trade name of Rid-Ezy ${ }^{\circledR}$.

Co-ral has been applied dermally as a 0.5 per cent spray. More recently this insecticide has been used in dipping vats at 0.25 per cent.

Intramuscular injections of dimethoate were used for cattle grub control, but systemically effective doses have produced toxicity, so that compound has not been tested further.

The most recent development in the application of systemic insecticides has been the pour-on technique. This method has bcen used to apply Ruelene [Rogoff \& Kohler (77); Scharff \& Ludwig (84)]. Studies with Co-ral at Kerrville [Drummond \& Graham (27)] have shown that in small-scale tests, pour-on treatments containing less than one-fourth of the active ingredient in the recommended spray treatment were as effective as the conventional spray. Equally effective were suspensions of wettable powder in water or light mineral oil, applied at 1 pint of 2 per cent Co-ral per animal, or at $1 / 2$ pint of 4 per cent or of 7.75 per cent.

Additional work by Graham (unpublished data) confirmed the work of Rosenberger (79), who reported that a solution of 2.0 per cent Dipterex in water at $11 / 2$ gal per head gave systemic control of cattle grubs. In addition, $4.0,7.75$, and 15.5 per cent solutions in proportionately smaller volumes applied to more limited areas of the body were highly effective. With Ruelene, results with emulsions and wettable powders as 0.5 per cent sprays applied over the entire body, and concentrates of 2.4 per cent and 7.75 per cent variously formulated and applied in proportionately smaller volumes to wet only a part of the body, were essentially similar.

It appears that dermal treatments of systemic insecticides should wet the skin for effective absorption, but the whole body need not be wet if sufficient concentrations are employed. This represents a great practical improvement in application of dermal systemics, since many ranchers do not have the spray equipment needed for thorough treatment with a dilute spray. The partial body treatment also overcomes the objection to wetting cattle over the entire body in cold weather.

During the past few years, several workers have published papers indi- 
cating promise for free-choice feeding of ronnel or Ruelene mixed either with feed or salt. In spite of these favorable reports, it is apparent that freechoice feeding of systemically active compounds in mixtures could be hazardous, because individual cattle vary so much in their appetites. These systemics can be given with less hazard if carefully fed in measured amounts of feed.

\section{Current Recommendations for Cattle Grub Control With Systemic Insecticides}

Current recommendations of the United States Department of Agriculture (90) for the application of systemic insecticides are that ronnel be administered orally as a bolus at a dosage of 100 to $110 \mathrm{mg} / \mathrm{kg}$ (one $37.5 \mathrm{gm}$ bolus containing 40 per cent ronnel per 300 pounds of body weight), or as a carefully weighed feed treatment at $7.8 \mathrm{mg} / \mathrm{kg}$ ( 0.3 pounds of feed containing 0.275 per cent ronnel per 100 pounds of body weight) fed daily for 14 days. Co-ral is recommended as a 0.5 per cent suspension of wettable powder, so sprayed that cattle are wet to the skin over the entire body, or as a 0.25 per cent dip. Ruelene is recommended as a 0.5 per cent spray or as a pour-on treatment at the rate of one ounce of 8.3 per cent active ingredient in water per 100 pounds of body weight.

Treatments should be applied after the heel fly season and at least one month before grubs begin encysting in the back of the animal. To avoid residues in meat, the minimum interval between treatment and slaughter should be 60 days for ronnel, 45 days for Co-ral, and 28 days for Ruelene.

The current recommendations afford an adequate margin of safety in normal use. This, however, presumes complete adherence to the specific directions stated on the label concerning the kind and age of animals to be treated, the proper season for treatment, and the proper time to be allowed between treatment and slaughter.

\section{Control of Other Pests with Systemic Insecticides}

In addition to research designed to develop a systemic insecticide for control of cattle grubs, a considerable amount of effort has been devoted to determining the effect of these chemicals on a variety of other parasites of livestock and other mammals. Some of the more recent results are reviewed in the following paragraphs.

Control of Gasterophilus bots in horses.-In ranch areas of the United States, bots (Gasterophilus spp.) are important economic pests of horses. Bolle (11), working in Germany, found oral treatments with Dipterex effective against horse bots. Drummond and his co-workers (28) tested a number of the most promising systemics to develop a recommendation for the control of horse bots. In order to perform these tests with economy, range horses, naturally infested with bots, were purchased from a dealer who slaughtered horses for dog food. The horses were brought to the laboratory and given insecticides at dosages which were not lethal to cattle in 
earlier tests. In preliminary tests, veterinarians administered the insecticides by stomach tube. Weighed amounts of the more promising compounds were subsequently mixed with ground feed and fed for a single day to the horses.

The horses were kept in individual pens for one week after treatment, and the manure was carefully collected and examined for precise counts on expelled bots. The horses were resold to the dealer for slaughter; then the entire gastrointestinal tracts were taken back to Kerrville for examination, and numbers of live and dead bots were recorded.

These studies showed that Dipterex and DDVP (2,2-dichlorovinyl dimethyl phosphate) were promising treatments for horse bot control. In other tests in Kentucky, Drudge et al. (21) found that dimethoate was effective against bots when administered for three to five days in feed.

Control of Oestrus ovis in sheep.-Peterson, Jones \& Cobbett (70) at the Albuquerque, New Mexico, laboratory of the Animal Disease and Parasite Research Division, found that ronnel, given as a drench to sheep, killed first-instar larvae of the sheep bot fly but did not control second- and thirdinstar larvae. Later, Peterson, Cobbett \& Meleney (69) found that intramuscular injections of dimethoate were highly effective against all three instars at dosages tolerated by sheep. More recently, these workers (71) have reported on the effectiveness of th two compounds mentioned above, as well as of a Co-ral dip, Dowco 109 given orally in capsules, Ruelene as a drench, and dimethoate added to the feed. In Mexico, Chavarria \& Carrillo (16) reported that oral treatments of Dipterex were effective against all instars. Oral doses of Ruelene were found by Miller et al. (63) also to be highly effective against all larval instars.

Drummond (25) tested 20 organophosphorus insecticides for sheep bot fly control. These insecticides were selected on the basis of their systemic activity as demonstrated in the guinea pig tests, and some of the compounds had also been effective against cattle grubs in small-scale tests.

Five of the 20 insecticides were 100 per cent effective against first-instar larvae, but not against second- and third-instar larvae. Three chemicals killed first- and second-, but not third-instar larvae. Three other phosphorus compounds were toxic to all three larval instars at dosages tolerated by sheep. The most promising compound was Bayer 37342 [O,O-dimethyl $O$ (3,5-dimethyl-4-methylthiophenyl)phosphorothioate], which was 100 per cent effective when given orally at $50 \mathrm{mg} / \mathrm{kg}$ and almost 100 per cent effective at $25 \mathrm{mg} / \mathrm{kg}$ body weight. It was indicated that the treatment could be administered either as a drench or mixed with weighed quantities of feed. Metabolism and residue studies need to be made with this new compound before it can be administered in field trials to privately owned animals.

Control of other parasites. - In addition to the host-parasite systemics mentioned above, systemic insecticides have been used in attempts to control other parasites of mammals.

Raffensperger (76) reported on the efficiency of ronnel administered orally to chickens for control of Menopon gallinae (Linnaeus), the shaft 
louse. Louse populations were reduced by high single oral doses (750 to 1000 $\mathrm{mg} / \mathrm{kg}$ ), but in feeding tests, chickens refused feed before levels reached $25 \mathrm{mg} / \mathrm{kg} /$ day. Kraemer \& Furman (49) found that Sevin ${ }^{\circledR}$ (1-naphthyl $N$ methylcarbamate) added to feed, was effective in ridding chickens of populations of the northern fowl mite, Ornithonyssus sylviarum (Canestrini \& Fanzago). The true systemic action was later demonstrated by a bioassay technique [Furman \& Pieper (31)]. Also, Harrison (39) found that high oral doses of Sevin were systemically effective against the chicken mite, Dermanyssus gallinae (De Geer), but control measures were impractical because of the feeding habits of the mite.

In studies on the hog sucking louse, Haematopinus suis (Linnaeus), De Leon et al. (19) found that single oral doses of Co-ral at $6.25 \mathrm{mg} / \mathrm{kg}$ were ineffective against nymphs and adults. However, Dipterex at 50 to 100 $\mathrm{mg} / \mathrm{kg}$ affected nymphs for a short period but did not affect adults.

In working with chlorinated hydrocarbon insecticides, Roulston (82) found that unctions or injections of lindane, aldrin, and dieldrin were effective against the tick Boophilus microplus (Canestrini). Most spectacular results were obtained in preventing establishment of larval ticks.

Considerable interest has been shown in attempts to control fleas on rats with oral doses of systemic insecticides. Harvey (40) found single oral doses of ronnel, Dowco 109, and dimethoate given to Norway rats, Rattus norvegicus (Erxleben), to be only partially effective against the oriental rat flea, Xenopsylla cheopis (Rothschild). In tests with the same host and parasite, Bennington (9) found that ronnel fed by free-choice in combination with an anticoagulant was effective in killing fleas before the rats died. Also, O'Berg \& Goulding (66) conducted tests with ronnel as a single oral treatment or as a low-level treatment in feed and obtained essentially the same information, but added that the contact toxicity of ronnel in feces of the rats may control larvae of rat fleas in nests of rodents.

Oral doses of ronnel or injections of dimethoate were ineffective against the dog follicle mite, Demodex canis Leydig, in dogs [Colgazier et al. (18)]. However, several authors, Lawrence (50), Vice \& Lawrence (91), and Johnson \& Kerley (44) have reported on the effectiveness of ronnel called Ectoral ${ }^{\circledR}$ for control of ectoparasites of dogs. Multiple oral doses, with or without topical treatments, were highly effective against ticks, fleas, and lice on dogs, but less effective against mange mites.

Also, the effectiveness of several systemic insecticides against larvae of the human bot fly or torsalo, Dermatobia hominis, has been investigated in Central and South America. Oral treatments of ronnel [Graham et al. (36)] and Dowco 109 [McGregor et al. (61)] apparently gave adequate control of larvae present in the cattle at time of treatment. Similar results with those same treatments and with dimethoate given orally and intramuscularly, Dowco 105® [0-(4-tert-butyl-2-chlorophenyl) O-methyl ethylphosphoramidothioate] and Co-ral, were reported by Graham et al. (35), with dimethoate given intramuscularly by Johnson (45), and with dimethoate intramuscu- 
larly and Dipterex dermally by Anderson (3). However, immediate reinfestation may preclude any widespread use of systemics for torsalo control.

\section{CONCLUSIONS}

Progress in the control of livestock insects by means of a systemic insecticide has been remarkable, when one considers that it has been only 19 years since Lindquist and his co-workers conducted the first successful laboratory test. During the following 14 years, most of the research was limited to studies in a few United States Department of Agriculture laboratories, but practical success with ronnel and Co-ral has greatly accelerated investigations. Most of the basic manufacturers of insecticides are now interested in developing chemicals for systemic control of livestock insects. Many state and Canadian workers have contributed to progress in this new field of research and development, and a considerable amount of research has been conducted in other countries. Presently recommended treatments do not consistently give 100 per cent control of cattle grubs in practical applications, but do give an average of 80 to 90 per cent control and therefore represent a great improvement over the rotenone sprays.

Certainly, the present recommendations represent only a beginning. New chemicals are being investigated in an effort to find compounds with higher insecticidal efficiency and lower mammalian toxicity. It is hoped that in a few years there will be systemic treatments so effective against insects and so well tolerated by animals that the compounds can be mixed with salt or minerals for free-choice feeding to livestock. When this time comes, systemic control of livestock insects will not be limited to the control of pests which are not easily controlled by ordinary sprays. The labor-saving advantages of letting cattle treat themselves will displace many conventional spray treatments which are now considered quite satisfactory for the control of arthropods.

Cattle grub control with systemic insecticides represents a major breakthrough. However, there are no really satisfactory recommendations as yet for the control of tabanids or mosquitoes attacking range cattle. None of the presently available treatments protect cattle more than a day or so from horse flies, deer flies, or mosquitoes. It may be that systemic insecticides mixed with salt or minerals, and constantly available in pastures, will solve this problem.

At present, there is no way to protect deer and other wildlife from ticks and insects. These parasites not only kill these animals, but frequently pest populations build up on these unprotected hosts so that the arthropods cause damage to livestock. Many wild animals also act as reservoirs of livestock diseases transmitted by insects. Systemic insecticides administered to these animals may lead to the reduction of transmission of diseases from wildlife to domestic animals. 


\section{LITERATURE CITED}

1. Adkins, T. R., Jr, and Arant, F. S. Systemic effect of Dipterex on the bed bug and Gulf Coast tick when administered to rabbits. J. Econ. Entomol., 50, 166-68 (1957)

2. Adkins, T. R., Jr., Sowell, W. L., and Arant, F. S. Systemic effect of selected chemicals on the bed bug and lone star tick when administered to rabbits. J. Econ. Entomol., 48, 139-41 (1955)

3. Andersen, E. H. Systemic insecticides for control of tropical warble fly (Dermatobia hominis) in cattle. Am. Vet. Med. Assoc. J., 139 (1), 104-7 (1961)

4. Barrett, W. L., Jr., and Wells, R. W. Transplantation of Hypoderma larvae and testing chemicals for control of larvae in experimental hosts. J. Econ. Entomol., 41, 77982 (1948)

5. Baxter, J. T. A field trial of the systemic insecticide Dow ET-57 against warble infestation in cattle. N. Ireland Min. Agr. Research and Exptl. Records, 8 (2), 73-81 (1959)

6. Beesley, W. N. Field trials with Trolene (Dow ET-57, ronnel, etrolene) against warble fly ( $H y p o-$ derma lineatum and $H$. bovis) grubs in cattle. Vet. Record, 72 (2), 21-23 (1960)

7. Beesley, W. N. Field trial with trichlorphon (Neguvon, Bayer L 13/ 59) against warble fly grubs in cattle. Vet. Record, 74 (5), 12729 (1962)

8. Beesley, W. N. Experimental techniques for evaluation of systemic insecticides against ox warble fly larvae. Exptl. Parasitol., 12 (2), 102-6 (1962)

9. Bennington, E. A systemic insecticide and bait for flea and rat control. J. Econ. Entomol., 53, 169-70 (1960)

10. Bolle, W. R. Neguvon, ein auszerlich und innerlich anwendbares Insektizid, Larvizid, und Acarizid. Vet.Med. Nachtr. Heft, 3, 155-59 (1956)

11. Bolle, W. R. Bekämpfung der Larven von Gasterophilus intestinalis mit Neguvon. Vet.-Med. Nachtr. Heft, 4, 3-12 (1957)

12. Brady, U. E., Dorough, H. W., and Arthur, B. W. Selective toxicity and animal systemic effectiveness of several organophosphates. $J$. Econ. Entomol., 53, 6-8 (1960)

13. Brundrett, H. M., McGregor, W. S., and Bushland, R. C. Systemic cattle grub control with Bayer 21/199 sprays. Agr. Chem., 12 (6), 36-37, 123,125 (1957)

14. Bushland, R. C. New research results with systemic insecticides. Proc. U. S. Livestock Sanit. Assoc., 62, 192-97 (1959)

15. Chamberlain, W.F., Gatterdam, P.'E., and Hopkins, D. E. The metabolism of $\mathrm{P}^{32}$-labeled dimethoate in sheep. J. Econ. Entomol., 54, 73340 (1961)

16. Chavarria, C. M., and Carrillo, A. R. Eine neuartige wirksame Behandlung der durch Oestrus ovis Linn. ausgelösten Myiasis. cavitaria. Zentr. Veterinärmed., 6 (9), 81624 (1959)

17. Claborn, H. V., Radeleff, R. D., and Bushland, R. C. Pesticide residues in meat and milk, U. S. Dept. Agr., ARS-33-63, 46 pp. (1960)

18. Colgazier, M. L., Enzie, F. D., and Wilkens, E. H. Some chemotherapeutic trials in canine demodectic mange. Proc. Helminthol. Soc. Wash. D.C., 27 (2), 139-45 (1960)

19. De Leon, D. D., Turk, R. D., and Hale, F. Observations on the control of Haematopinus suis and Ascaris lumbricoides of swine with certain organic phosphorous compounds. Am. Vet. Med. Assoc. J., 138 (4), 179-83 (1961)

20. Dorough, H. W., and Arthur, B. W. Systemic and contact insecticidal effectiveness of selected chemicals administered orally or dermally to rabbits. J. Econ. Entomol., 54, 993-96 (1961)

21. Drudge, J. H., Leland, S. E., Wyant, Z. N., Elam, G. W., and Lyons, E. T. Critical tests with the organic phosphate insecticide, dimethoate, against Gasterophilus spp. in the horse, with observations on its anthelmintic action. Am. J. Vet. Research, 22, 1106-11 (1961)

22. Drummond, R. O. Laboratory screening tests of animal systemic insecticides. J. Econ. Entomol., 51, 425-27 (1958)

23. Drummond, R. O. Preliminary eval- 
uation of animal systemic insecticides. J. Econ. Entomol., 53, 112527 (1960)

24. Drummond, R. O. Compounds screened as animal systemic insecticides at Kerrville, Texas, 1953-59. U. $S$. Dept. Agr., ARS-33-64, 50 pp. (1961)

25. Drummond, R. O. Control of Oestrus ovis in sheep with systemic insecticides. J. Parasitol., 48, 211-14 (1962)

26. Drummond, R. O. Further evaluation of animal systemic insecticides, 1961. J. Econ. Entomol., 55, 398402 (1962)

27. Drummond, R. O., and Graham, O. H. Low-volume dermal applications and injections of Co-Ral for systemic control of cattle grubs. $J$. Econ. Entomol., 55, 255-58 (1962)

28. Drummond, R. O., Jackson, J. B., Gless, E. E., and Moore, B. Systemic insecticides for the control of Gasterophilus bots in horses. Agr. Chem., 14 (12), 41-43, 100 (1959)

29. Flynn, A. D., and Eden, W. G. Systemic insecticidal action on bloodsucking ectoparasites of several compounds administered orally to rabbits. J. Econ. Entomol., 51, 499-501 (1958)

30. Flynn, A. D., and Eden, W. G. Systemic and topical insecticidal activity of some substituted phosphates and phosphorothioates. J. Econ. Entomol., 53, 692-93 (1960)

31. Furman, D. P., and Pieper, G. R. Systemic acaricidal effects of Sevin in poultry. J, Econ. Entomol., 55, 355-57 (1962)

32. Garnham, P. C. C. Mortality of Aedes aegypti feeding on rabbits receiving oral "Gammexane." Nature, 160, 156-57 (1947)

33. Grahzm, O. H. Tests with Bayer 21/199 for the control of cattle grubs. J. Econ. Entomol., 51, 35960 (1958)

34. Graham, O. H. Techniques for evaluating systemic insecticides against livestock insects. Methods of Testing Chemicals on Insects, 2, Chap. 13, 200-16 (Burgess Publ. Co., Minneapolis, Minn., 248 pp., 1960)

35. Graham, O. H., Kraemer, P., and Osorio, A. Control del torsalo (Dermatobia hominis, L., Jr.) con insecticidas organicos fosforados, de accion sistemica. Turrialba, 8 (4), 153-57 (1958)
36. Graham, O. H., Wade, L. L. Colby, R. W., and McGregor, W. S. Use of Dow ET-57 for the systemic control of Dermatobia hominis in cattle. Agr. Chem., 12 (10), 51, 109 (1957)

37. Grunin, K. Ya. The Soviet literature on Oestridae Sensu Latu (Diptera) published in 1957. Entomol. Obozrenie, 38 (1), 265 (1959); Engl. transl., Entomol. Rev., 38 (1), 246-52 (1959)

38. Grunin, K. Ya. The Soviet literature on Oestridae Sensu Latu (Diptera), published in 1958 and 1959. Entomol. Obozrenie, 40 (1), 24045 (1961) ; Engl. transl., Entomol. Rev., 40 (1), 126-30 (1961)

39. Harrison, I. R. The control of poultry red mite with 1-naphthyl-N-methyl carbamate. Vet. Record, 72 (16), 298-300 (1960)

40. Harvey, T. L. Control of the oriental rat flea with systemic insecticides fed to rats. J. Econ. Entomol., 53, 167-68 (1960)

41. Hatch, C. Use of etrolene against the warble fly (Hypoderma). Irish Vet. J., 14 (1), 14-15 (1960)

42. Hewitt, R., Brebbia, A., and Waletzky, E. Carbamoyl alkyl phosphorodithioates as chemotherapeutic agents: Screening by aedicidal properties in laboratory mammals, lambs and calves. J. Econ. Entomol., 51, 12631 (1958)

43. Hewitt, R., Emro, J., Entwistle, J., Pankavich, J., Thorson, R., Wallace, W., and Waletzky, E. Carbamoyl alkyl phosphorodithioates as chemotherapeutic agents : Effects of dimethoate against cattle grubs in cattle. J. Econ. Entomol., 51, 445-50 (1958)

44. Johnson, R. V., and Kerley, T. L. Ectoral as a systemic insecticide. Allied Vet., 33 (3), 67-72 (1962)

45. Johnson, W. P. The effect of dimethoate on Dermatobia hominis in cattle. Am. J. Vet. Research, 21, 1046-48 (1960)

46. Jones, R. H., Brundrett, H. M., and Radeleff, R. D. Ranch tests against cattle grubs with the systemic insecticide Dow ET-57. Agr. Chem., 12 (7), 45, 95-96 (1957)

47. Kenny, J. E., and Thornbury, H. Systemic insecticides with special reference to Dow ET-57. Irish Vet. J., 12 (1), 4-5 (1958)

48. Knipling, E. F., Bushland, R. C., Babers, F. H., Culpepper, G. H., 
and Raun, E. S. Evaluation of selected insecticides and drugs as chemotherapeutic agents against external bloodsucking parasites. $J$. Parasitol., 34, 55-70 (1948)

49. Kraemer, P., and Furman, D. P. Systemic activity of Sevin in control of Ornithonyssus sylviarum (C. \& F.). J. Econ. Entomol., 52, 17071 (1959)

50. Lawrence, W. A. Dog tick control with an orally administered acaricide. Modern Vet. Pract., 41 (17), 70-71 (1960)

51. Lindquist, A. W. A promising systemic insecticide for control of cattle grubs. Proc. Ann. Conf. N. Central States Entomologists, 35th Conf., 11, 3น4 (1956)

52. Lindquist, A. W. Systemic insecticides for control of cattle grubs (Hypoderma) and other livestock insects. Proc. U. S. Livestock Sanit. Assoc., 61, 217-24 (1958)

53. Lindquist, A. W., Knipling, E. F., Jones, H. A., and Madden, A. H. Mortality of bed bugs on rabbits given oral dosages of DDT and pyrethrum. J. Econ. Entomol., 37, 128 (1944)

54. Lindquist, A. W., Roth, A. R., Hoffman, R. A., and Yates, W. W. Chemotherapeutic use of insecticides for control of bloodsucking insects. J. Econ. Entomol., 46, 61014 (1953)

55. McDuffie, W. C. The development of systemic insecticides for the control of cattle grubs. Worcestershire Agr. Chron., (G. Brit.), 39 (1958)

56. McGregor, W. S., and Bushland, R. C. Research on the use of systemic insecticides for the control of livestock pests. J. Econ. Entomol., 49, 86-88 (1956)

57. McGregor, W. S., and Bushland, R. C. Tests with Dow ET-57 against two species of cattle grubs. $J$. Econ. Entomol., 50, 246-49 (1957)

58. McGregor, W. S., Ludwig, P. D., and Wade, L. L. Progress report on Ruelene for cattle grub control. Down Earth, 15 (2), 2-3 (1959)

59. McGregor, W. S., Radeleff, R. D., and Bushland, R. C. Some phosphorus compounds as systemic insecticides against cattle grubs. J. Econ. Entomol., 47, 465-67 (1954)

60. McGregor, W. S., Radeleff, R. D., Claborn, H. V., and Bushland, R. C. Dieldrin, aldrin and lindane as systemic insecticides against livestock pests. Agr. Chem., 10 (1), 34-36, 123 (1955)

61. McGregor, W. S., Wade, L. L., and Colby, R. R. Systemic control of Dermatobia hominis (L., Jr.) in Central and South American cattle with Narlene insecticide. J. Econ. Entomol., 51, 724-25 (1958)

62. de Meillon, B. Effects on some bloodsucking arthropods of "Gammexane" when fed to a rabbit. Nature, 158, 839 (1946)

63. Miller, J. H., Johnson, H. E., and Stout, A. L. Effects of organic phosphoramidate (Ruelene) in control of nasal botfly (Oestrus ovis) in sheep. Am. Vet. Med. Assoc. J., 138 (8), 431-33 (1961)

64. Nardi, E., and Lellis, M. Experiment in the prevention of bovine hypodermosis with a phosphoric ester "Neguvon" used orally. (Ital.) Parassetologia, 2 (1/2), 261-69 (1960)

65. Nemcseri, L. Control of Hypoderma bovis larvae. (Hungarian) Magyar Mezogazdasag., 16 (31), 21 (1961)

64. Nardi, E., and Lellis, M. Experiment effect of ronnel fed to rats for the control of oriental rat fleas. Oregon State Univ. Agr. Expt. Sta. Misc. Paper 131, 11 pp. (1962)

67. Pearson, J. K. L., and Baxter, J. T. A. A further report on etrolene and warble infestations in cattle. Brit. Vet. J., 117 (11), 497-501 (1961)

68. Peterson, D. G., and Kingscote, A. A. Control of animal parasites with systemic insecticides. Can. J. Biochem. Physiol., 37, 1105-11 (1959)

69. Peterson, H. O., Cobbett, N. G., and Meleney, W. P. Treatment of Oestrus ovis with dimethoate. Vet. Med., 54, 377-83 (1959)

70. Peterson, H. O., Jones, E. M., and Cobbett, N. G. Effectiveness of Dow ET-57 (Trolene) against the nasal botfly of sheep. Am. J. Vet. Research, 19, 120-31 (1958)

71. Peterson, H. O., Meleney, W. P., and Cobbett, N. G. The use of organic phosphorous compounds in destroying Oestrus ovis larvae. Proc. U. S. Livestock Sanit. Assoc., 62, 1-9 (1959)

72. Plapp, F. W., Jr., Chamberlain, W. F., and Radeleff, R. D. Systemic insecticides in animals. The nature and fate of chemicals applied to soils, plants and animals, 160-69, 
U. S. Dept. Agr., AR.S 20-9, 221 pp. (1960)

73. Radeleff, R. D., and Bushland, R. C. Benzene hexachloride poisoning of emaciated sheep. Vet. Med., 48 (2), 53-58 (1953)

74. Radeleff, R. D., and Bushland, R. C. The toxicity of pesticides for livestock. The nature and fate of chemicals applied to soils, plants and animals, 134-59, U. S. Dept. Agr., ARS 20-9, 221 pp. (1960)

75. Radeleff, R. D., and Woodard, G. T. Toxicological studies of Dow ET57 in cattle and sheep. J. Econ. Entomol., 50, 249-51 (1957)

76. Raffensperger, E. M. The effects of Dow ET-57 on chicken shaft louse infestations. J. Econ. Entomol., 51, 558-59 (1958)

77. Rogoff, W. M., and Kohler, P. H. Effectiveness of Ruelene applied as localized "pour-on" and as spray for cattle grub control. J. Econ. Entomol., 53, 814-17 (1960)

78. Rosenberger, G. Ein neuer Weg der Dasselbekãmpfung-erfolgreiche Behandlung der Rinder gegen die Wanderlarven. Deut. Tierarztl. Wochschr., 64 (16), 441-47 (1957)

79. Rosenberger. G. Sprühbehandlung mit systemisch wirksamen Mitteln zur Dasselbekämpfung. Deut. Tierarztl. Wochscho., 66, 549-54 (1959)

80. Rosenberger, G. Vergleichende Versuche mit dem Neguvon-Spruhund-Ruckenwaschverfahren im Frïhjahr zur Dasselbekāmpfung. Deut. Tieraratl. Wochschr., 67 (20), 558-60 (1960)

81. Roth, A. R., and Eddy, G. W. Tests with Dow ET-57 against cattle grubs in Oregon. J. Econ. Entomol., 50, 244-46 (1957)

82. Roulston, W. J. The effects of some chlorinated hydrocarbons as systemic acaricides against the cattle tick Boophilus microplus. Australian J. Agr. Research, 7, (6), 60824 (1956)

83. Sassen, D., and Otte, B. Neguvon bei der Bekäompfung das Dassellarvenbefalls in der Wesermarsch. Vet.-Med. Nachtr., 2, 8286 (1959)

84. Scharff, D. K., and Ludwig, P. D.
Cattle grub control with Ruelene as a dip and a pour-on treatment. J. Econ. Entomol., 55, 191-92 (1962)

85. Sharma, R. M., Dyal, R. S., and Chawla, L. R. Systemic insecticides in the control of cattle grubs. Vet. Record., 72 (43), 898-901 (1960)

86. Smith, C. L., and Richards, R. New insecticides for control of the cattle grub. J. Econ. Entomol., 47, 712-13 (1954)

87. Stoenescu, A., Cefranov, N., Minascurta, C., and Wechsler, A. Studies on the effectiveness of the product "Neguvon" in the treatment of bovine hypodermosis. Inst. Patol. Igiena Animala Prob. Parazitol. Vet., 7, 15-26 (1959)

88. Stones, L. C. The systemic use of insecticides in domestic animals. Chem. \& Indus. (London), 41, 1643-50 (1961)

89. deToledo, A. A., and Saur, H. F. G. The effects of certain chlorinated insecticides on the warble fly. $B i$ ologico, 16, 25-34 (1950)

90. U. S. Department of Agriculture. Insecticide recommendations of the Entomology Research Division for the control of insects attacking crops and livestock for $1962, U$. S. Dept. Agr., Agr. Handbook No. 120, 139, 152 pp. (1962)

91. Vice, T. E., and Lawrence, W. A. Oral insecticide (ronnel) for ticks and fleas on dogs. Modern Vet. Pract., 42 (8), 55, 58-59 (1961)

92. Weidhaas, D. E., Schmidt, C. H., and Chamberlain, W. F. Metabolism of radio-labelled systemic insecticides in animals. Radioisotopes and $\mathrm{Ra}$ diation in Entomology, Intern. Atomic Energy Agency, Tech. Rept. Ser., 93-98 (1962)

93. Weintraub, J. Inducing mating and oviposition of the warble flies $H y$ poderma bovis (L.) and $H$. lineatum (De Vill.) in captivity. Can. Entomologist, 93, 149-56 (1961)

94. Weintraub, J., McGregor, W. S., and Brundrett, H. M. Artificial infestations of the northern cattle grub, Hypoderma bovis, in Texas. $J$. Econ. Entomol., 54, 84-87 (1961) 